ISSN 1420-3049

www.mdpi.com/journal/molecules

Article

\title{
Diterpene Glycosides from Stevia rebaudiana
}

\section{Venkata Sai Prakash Chaturvedula *, Mani Upreti and Indra Prakash}

The Coca-Cola Company, Organic Chemistry Department, Research and Technology, One Coca-Cola Plaza, Atlanta, GA 30313, USA

* Author to whom correspondence should be addressed; E-Mail: vchaturvedula@na.ko.com; Tel.: +1-404-676-9257; Fax: +1-404-598-9257.

Received: 24 March 2011; in revised form: 16 April 2011 / Accepted: 20 April 2011 /

Published: 28 April 2011

\begin{abstract}
Three novel diterpene glycosides were isolated for the first time from the commercial extract of the leaves of Stevia rebaudiana, along with several known steviol glycosides, namely stevioside, rebaudiosides A-F, rubusoside and dulcoside A. The new compounds were identified as 13-[(2-O- $\beta$-D-glucopyranosyl-3-O- $\beta$-D-glucopyranosyl- $\beta$-Dglucopyranosyl)oxy] ent-kaur-15-en-19-oic acid (1), 13-[(2-O- $\beta$-D-glucopyranosyl-3-O- $\beta$ D-glucopyranosyl- $\beta$-D-glucopyranosyl)oxy]-16 $\beta$-hydroxy-ent-kauran-19-oic acid (2) and 13-methyl-16-oxo-17-nor-ent-kauran-19-oic acid- $\beta$-D-glucopyranosyl ester (3) on the basis of extensive 2D NMR and MS spectroscopic data as well as chemical studies.
\end{abstract}

Keywords: Stevia rebaudiana; Compositae; Asteraceae; diterpenoid glycosides; spectral data; chemical studies

\section{Introduction}

Stevia rebaudiana (Bertoni) Bertoni is a perennial shrub belonging to the family of Asteraceae (Compositae) native to Brazil and Paraguay, but now grown commercially in a number of countries, particularly in Japan, Taiwan, Korea, Thailand and Indonesia [1-2]. Extracts of the leaves of $S$. rebaudiana have been used for decades to sweeten food and beverages in Japan, South America and China. The major constituents in the leaves of $S$. rebaudiana are the potently sweet diterpenoid glycosides stevioside, rebaudiosides $\mathrm{A}$ and $\mathrm{D}$, and dulcoside $\mathrm{A}$. These compounds, which are known as Stevia sweeteners, are the glycosides of the diterpene steviol, ent-13-hydroxykaur-16-en-19-oic acid [3]. 
As a part of our continuing research to discover natural sweeteners [4-5], we have collected commercial extracts of $S$. rebaudiana from various suppliers all over the World. This paper describes the isolation of three diterpene glycosides 1-3 isolated for the first time from the crude extract of the leaves of S. rebaudiana obtained from ShenZhen NII Natural Food Ingredient Co. Ltd, China and their identification based on extensive spectroscopic (NMR and MS) and chemical studies.

\section{Results and Discussion}

Purification of the commercial extract of $S$. rebaudiana obtained as Lot No: 20071003 from ShenZhen NII Natural Food Ingredient Co. Ltd, China, resulted in the isolation of three new diterpenoid glycosides 1-3, and the known steviol glycosides, stevioside, rebaudiosides A-F, rubusoside and dulcoside A (Figure 1). The structures of the known compounds were identified in comparison of their retention times with authentic standards using the HPLC-MS method as described previously [6] and the spectral data that were reported in the literature [7-13].

Figure 1. Structures of 1-3.

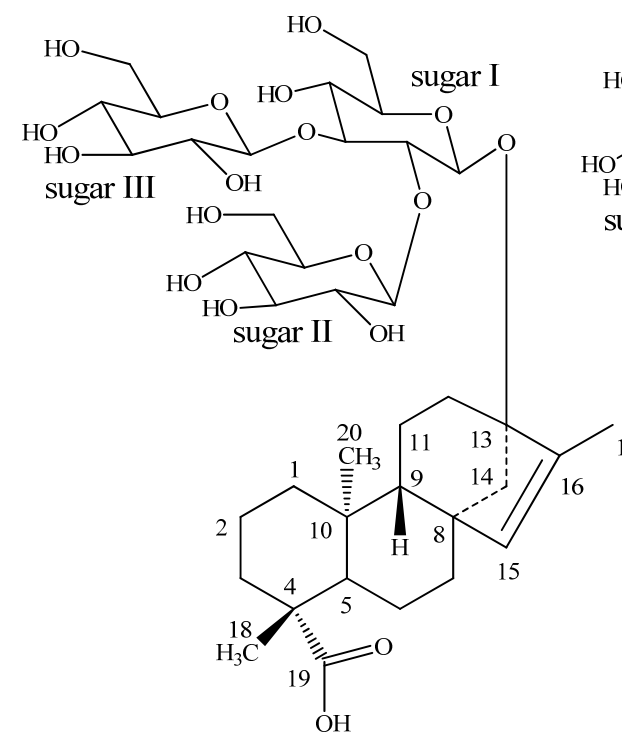

1

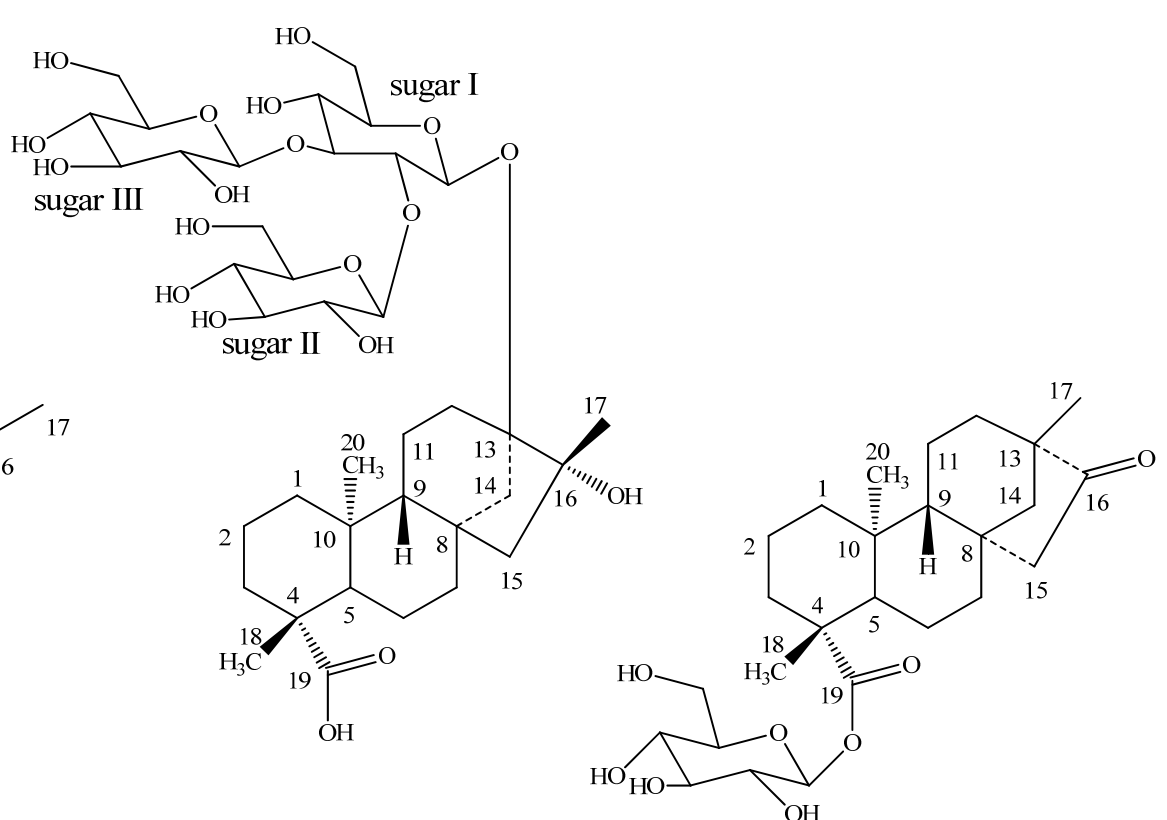

2
3

Compound 1 was obtained as a white powder and its molecular formula was assigned as $\mathrm{C}_{38} \mathrm{H}_{60} \mathrm{O}_{18}$ from its HRESI mass spectrum, which showed a $(\mathrm{M}+\mathrm{Na})^{+}$ion at $m / z$ 827.3661; this was supported by the ${ }^{13} \mathrm{C}$-NMR spectral data. The ${ }^{1} \mathrm{H}-\mathrm{NMR}$ spectrum of $\mathbf{1}$ (Table 1) showed the presence of three methyl singlets at $\delta 0.99,1.17$, and 1.72, eight methylene and two methine protons between $\delta 0.86-2.23$, and a trisubstituted olefinic proton at $\delta 5.14$, similar to ent-13-hydroxykaur-15-en-19-oic acid [15]. The basic skeleton of kaurane diterpenoids was supported by COSY (H-1/H-2; H-2/H-3; H-5/H-6; H-6/H-7; $\mathrm{H}-9 / \mathrm{H}-11 ; \mathrm{H}-11 / \mathrm{H}-12)$ and HMBC (H-1/C-2, C-10; H-3/C-1, C-2, C-4, C-5, C-18, C-19; H-5/C-4, C-6, C-7, C-9, C-10, C-18, C-19, C-20; H-9/C-8, C-10, C-11, C-12; H-14/C-8, C-9, C-13, C-15, C-16 
and H-17/C-13, C-15, C-16) correlations (Figure 2). In addition, the ${ }^{1} \mathrm{H}-\mathrm{NMR}$ spectrum of 1 also showed three anomeric protons as doublets at $\delta 4.66(J=7.8 \mathrm{~Hz}), 4.85(J=7.8 \mathrm{~Hz})$, and $4.82(J=7.8 \mathrm{~Hz})$ suggesting the presence in its structure of three sugar units, which was supported by the fragment ions observed at $\mathrm{m} / \mathrm{z}$ 643, 481, and 319 in the ESI MS/MS spectrum corresponding to the successive loss of three hexose moieties from its $[\mathrm{M}+\mathrm{H}]^{+}$ion. Enzymatic hydrolysis of $\mathbf{1}$ furnished a compound which was found identical to ent-13-hydroxykaur-15-en-19-oic acid on the basis of NMR spectral data [13-14]. Acid hydrolysis of $\mathbf{1}$ afforded D-glucose that was identified by preparing the corresponding thiocarbamoyl-thiazolidine carboxylate derivative with L-cysteine methyl ester and $O$-tolyl isothiocyanate, and in comparison of its retention time with the standard sugars as described in the literature comparison [15].

Table 1. ${ }^{1} \mathrm{H}-\mathrm{NMR}$ chemical shift values for 1-3 isolated from Stevia rebaudiana recorded in $\mathrm{CD}_{3} \mathrm{OD}{ }^{\mathrm{a}}$.

\begin{tabular}{|c|c|c|c|}
\hline Position & 1 & 2 & 3 \\
\hline 1 & $\begin{array}{l}0.86(\mathrm{~m}, 1 \mathrm{H}), 1.86(\mathrm{~m}, \\
1 \mathrm{H})\end{array}$ & $\begin{array}{l}0.86(\mathrm{~m}, 1 \mathrm{H}), 1.86(\mathrm{~m}, \\
1 \mathrm{H})\end{array}$ & $\begin{array}{l}0.97(\mathrm{~m}, 1 \mathrm{H}), 1.71(\mathrm{~m}, \\
1 \mathrm{H})\end{array}$ \\
\hline 2 & $\begin{array}{l}1.39(\mathrm{~m}, 1 \mathrm{H}), 1.90(\mathrm{~m}, \\
1 \mathrm{H})\end{array}$ & $\begin{array}{l}1.42(\mathrm{~m}, 1 \mathrm{H}), 1.94(\mathrm{~m}, \\
1 \mathrm{H})\end{array}$ & $\begin{array}{l}1.38(\mathrm{~m}, 1 \mathrm{H}), 1.90(\mathrm{~m}, \\
1 \mathrm{H})\end{array}$ \\
\hline 3 & $\begin{array}{l}1.02(\mathrm{~m}, 1 \mathrm{H}), 2.10(\mathrm{~d} \\
11.9,1 \mathrm{H})\end{array}$ & $\begin{array}{l}1.00(\mathrm{~m}, 1 \mathrm{H}), 2.12(\mathrm{~d}, \\
12.6,1 \mathrm{H})\end{array}$ & $\begin{array}{l}1.08(\mathrm{~m}, 1 \mathrm{H}), 2.18(\mathrm{~d}, \\
13.7,1 \mathrm{H})\end{array}$ \\
\hline 5 & $1.08(\mathrm{~m}, 1 \mathrm{H})$ & $1.07(\mathrm{~m}, 1 \mathrm{H})$ & $1.22(\mathrm{~m}, 1 \mathrm{H})$ \\
\hline 6 & $\begin{array}{l}1.52(\mathrm{~m}, 1 \mathrm{H}), 1.83(\mathrm{~m}, \\
1 \mathrm{H})\end{array}$ & $\begin{array}{l}1.82(\mathrm{~m}, 1 \mathrm{H}), 1.97(\mathrm{~m}, \\
1 \mathrm{H})\end{array}$ & $1.90(\mathrm{~m}, 2 \mathrm{H})$ \\
\hline 7 & $\begin{array}{l}1.50(\mathrm{~m}, 1 \mathrm{H}), 1.58(\mathrm{~m}, \\
1 \mathrm{H})\end{array}$ & $\begin{array}{l}1.37(\mathrm{~m}, 1 \mathrm{H}), 1.58(\mathrm{~m}, \\
1 \mathrm{H})\end{array}$ & $\begin{array}{l}1.49(\mathrm{~m}, 1 \mathrm{H}), 1.68(\mathrm{~m}, \\
1 \mathrm{H})\end{array}$ \\
\hline 9 & $0.86(\mathrm{~m}, 1 \mathrm{H})$ & $0.93(\mathrm{t}, J=7.8 \mathrm{~Hz}, 1 \mathrm{H})$ & $1.24(\mathrm{~m}, 1 \mathrm{H})$ \\
\hline 11 & $\begin{array}{l}1.50(\mathrm{~m}, 1 \mathrm{H}), 1.69(\mathrm{~m}, \\
1 \mathrm{H})\end{array}$ & $\begin{array}{l}1.65(\mathrm{~m}, 1 \mathrm{H}), 1.85(\mathrm{~m} \\
1 \mathrm{H})\end{array}$ & $\begin{array}{l}1.23(\mathrm{~m}, 1 \mathrm{H}), 1.68(\mathrm{~m}, \\
1 \mathrm{H})\end{array}$ \\
\hline 12 & $\begin{array}{l}1.63(\mathrm{~m}, 1 \mathrm{H}), 1.67(\mathrm{~m}, \\
1 \mathrm{H})\end{array}$ & $\begin{array}{l}1.80(\mathrm{~m}, 1 \mathrm{H}), 1.04(\mathrm{~m}, \\
1 \mathrm{H})\end{array}$ & $\begin{array}{l}1.43(\mathrm{~m}, 1 \mathrm{H}), 1.53(\mathrm{~m}, \\
1 \mathrm{H})\end{array}$ \\
\hline 14 & $\begin{array}{l}1.68(\mathrm{~m}, 1 \mathrm{H}), 2.23(\mathrm{~d} \\
10.0,1 \mathrm{H})\end{array}$ & $\begin{array}{l}1.84(\mathrm{~m}, 1 \mathrm{H}), 1.98(\mathrm{~d}, \\
10.0,1 \mathrm{H})\end{array}$ & $\begin{array}{l}1.45(\mathrm{~m}, 1 \mathrm{H}), 1.56(\mathrm{~m}, \\
1 \mathrm{H})\end{array}$ \\
\hline 15 & $5.14(\mathrm{~s}, 1 \mathrm{H})$ & $\begin{array}{l}1.42(\mathrm{~d}, 13.7,1 \mathrm{H}), 1.60 \\
(\mathrm{~d}, 13.7,1 \mathrm{H})\end{array}$ & $\begin{array}{l}1.84(\mathrm{~m}, 1 \mathrm{H}), 2.63(\mathrm{dd} \\
3.3,18.9,1 \mathrm{H})\end{array}$ \\
\hline 17 & $1.72(\mathrm{~s}, 3 \mathrm{H})$ & $1.27(\mathrm{~s}, 3 \mathrm{H})$ & $0.81(\mathrm{~s}, 3 \mathrm{H})$ \\
\hline 19 & $1.17(\mathrm{~s}, 3 \mathrm{H})$ & $1.16(\mathrm{~s}, 3 \mathrm{H})$ & $1.23(\mathrm{~s}, 3 \mathrm{H})$ \\
\hline 20 & $0.99(\mathrm{~s}, 3 \mathrm{H})$ & $0.98(\mathrm{~s}, 3 \mathrm{H})$ & $0.94(\mathrm{~s}, 3 \mathrm{H})$ \\
\hline $1^{\prime}$ & $4.66(\mathrm{~d}, 7.8,1 \mathrm{H})$ & $4.66(\mathrm{~d}, 8.2,1 \mathrm{H})$ & $5.39(\mathrm{~d}, 8.2,1 \mathrm{H})$ \\
\hline $2^{\prime}$ & $3.57(\mathrm{~m}, 1 \mathrm{H})$ & $3.56(\mathrm{~m}, 1 \mathrm{H})$ & $3.33(\mathrm{dd}, 7.5,8.0,1 \mathrm{H})$ \\
\hline $3^{\prime}$ & $3.77(\mathrm{~m}, 1 \mathrm{H})$ & $3.74(\mathrm{~m}, 1 \mathrm{H})$ & $3.43(\mathrm{dd}, 8.2,8.9,1 \mathrm{H})$ \\
\hline $4^{\prime}$ & $3.36(\mathrm{~m}, 1 \mathrm{H})$ & $3.34(\mathrm{~m}, 1 \mathrm{H})$ & $3.32(\mathrm{dd}, 8.4,9.2,1 \mathrm{H})$ \\
\hline $5^{\prime}$ & $3.28(\mathrm{~m}, 1 \mathrm{H})$ & $3.30(\mathrm{~m}, 1 \mathrm{H})$ & $\begin{array}{l}3.36(\mathrm{ddd}, 8.4,1.8,6.9 \\
1 \mathrm{H})\end{array}$ \\
\hline $6^{\prime}$ & $\begin{array}{l}3.64(\mathrm{~m}, 1 \mathrm{H}), 3.80(\mathrm{~m}, \\
1 \mathrm{H})\end{array}$ & $\begin{array}{l}3.67(\mathrm{~m}, 1 \mathrm{H}), 3.88(\mathrm{~m}, \\
1 \mathrm{H})\end{array}$ & $\begin{array}{l}3.67(\mathrm{dd}, 2.1,11.4,1 \mathrm{H}) \\
3.80(\mathrm{dd}, 4.2,12.2,1 \mathrm{H})\end{array}$ \\
\hline
\end{tabular}


Table 1. Cont.

\begin{tabular}{|l|l|l|l|}
\hline $1^{\prime \prime}$ & $4.85(\mathrm{~d}, 7.8,1 \mathrm{H})$ & $4.89(\mathrm{~d}, 7.8,1 \mathrm{H})$ & \\
$2^{\prime \prime}$ & $3.24(\mathrm{~m}, 1 \mathrm{H})$ & $3.25(\mathrm{~m}, 1 \mathrm{H})$ & \\
$3^{\prime \prime}$ & $3.32(\mathrm{~m}, 1 \mathrm{H})$ & $3.42(\mathrm{~m}, 1 \mathrm{H})$ & \\
$4^{\prime \prime}$ & $3.33(\mathrm{~m}, 1 \mathrm{H})$ & $3.32(\mathrm{~m}, 1 \mathrm{H})$ & \\
$5^{\prime \prime}$ & $3.33(\mathrm{~m}, 1 \mathrm{H})$ & $3.36(\mathrm{~m}, 1 \mathrm{H})$ & \\
$6^{\prime \prime}$ & $3.56(\mathrm{~m}, 1 \mathrm{H}), 3.81(\mathrm{~m}$, & $3.60(\mathrm{~m}, 1 \mathrm{H}), 3.80(\mathrm{~m}$, & \\
& $1 \mathrm{H})$ & $1 \mathrm{H})$ & \\
$1^{\prime \prime \prime}$ & $4.72(\mathrm{~d}, 7.8,1 \mathrm{H})$ & $4.74(\mathrm{~d}, 7.8,1 \mathrm{H})$ & \\
$2^{\prime \prime \prime}$ & $3.27(\mathrm{~m}, 1 \mathrm{H})$ & $3.25(\mathrm{~m}, 1 \mathrm{H})$ & \\
$3^{\prime \prime \prime}$ & $3.33(\mathrm{~m}, 1 \mathrm{H})$ & $3.32(\mathrm{~m}, 1 \mathrm{H})$ & \\
$4^{\prime \prime \prime}$ & $3.32(\mathrm{~m}, 1 \mathrm{H})$ & $3.32(\mathrm{~m}, 1 \mathrm{H})$ & \\
$5^{\prime \prime \prime}$ & $3.36(\mathrm{~m}, 1 \mathrm{H})$ & $3.36(\mathrm{~m}, 1 \mathrm{H})$ & \\
$6^{\prime \prime \prime}$ & $3.67(\mathrm{~m}, 1 \mathrm{H}), 3.71(\mathrm{~m}$, & $3.65(\mathrm{~m}, 1 \mathrm{H}), 3.80(\mathrm{~m}$, & \\
& $1 \mathrm{H})$ & $1 \mathrm{H})$ & \\
\hline
\end{tabular}

${ }^{\mathbf{a}}$ assignments made on the basis of COSY, HSQC and HMBC correlations; ${ }^{\mathbf{b}}$ Chemical shift values are in $\delta(\mathrm{ppm}) ;{ }^{\mathrm{c}}$ Coupling constants are in $\mathrm{Hz}$.

Figure 2. Key COSY and HMBC correlations of 1.

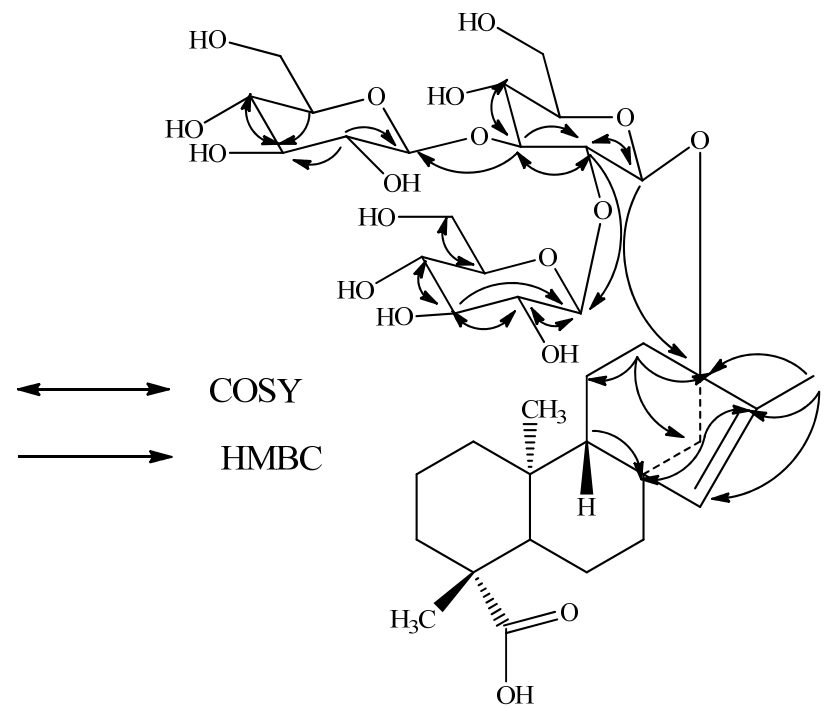

The ${ }^{1} \mathrm{H}$ - and ${ }^{13} \mathrm{C}-\mathrm{NMR}$ values for all the protons and carbons were assigned on the basis of COSY, HSQC and HMBC correlations (Figure 2) and are given in Tables 1 and 2. A close comparison of the ${ }^{1} \mathrm{H}$ - and ${ }^{13} \mathrm{C}-\mathrm{NMR}$ values of $\mathbf{1}$ with those of rebaudioside A suggested a 2,3-branched $\beta$-D-glucotriosyl substituent at $\mathrm{C}-13$ as well as the absence of a glucosyl unit at $\mathrm{C}-19$ and migration of the exocyclic double bond from $\mathrm{C}-16 / \mathrm{C}-17$ to $\mathrm{C}-15 / \mathrm{C}-16$. This was supported by the ${ }^{13} \mathrm{C}-\mathrm{NMR}$ values for the trisubstituted double bond between $\mathrm{C}-15$ and $\mathrm{C}-16$ which were observed at $\delta 136.1$ and 142.6, respectively, and also from the HMBC correlations: H-12/C-9, C-11, C-13, C-14, C-16; H-15/C-8, C-9, C-14, C-16, C-17 and H-17/C-13, C-15, C-16. The large coupling constants observed for the three D-glucose anomeric protons suggested the $\beta$-orientation as reported for steviol glycosides [6-13]. Thus, structure of 1 was established as 13-[(2-O- $\beta$-D-glucopyranosyl-3-O- $\beta$-D-glucopyranosyl- $\beta$-Dglucopyranosyl)oxy] ent-kaur-15-en-19-oic acid. 
Table 2. ${ }^{13} \mathrm{C}$ NMR chemical shift values for $\mathbf{1}-\mathbf{3}$ isolated from Stevia rebaudiana recorded in $\mathrm{CD}_{3} \mathrm{OD}{ }^{\mathrm{a}}$.

\begin{tabular}{|c|c|c|c|}
\hline Position & 1 & 2 & 3 \\
\hline 1 & 40.9 & 42.0 & 39.7 \\
\hline 2 & 19.1 & 19.0 & 19.2 \\
\hline 3 & 37.9 & 38.0 & 38.1 \\
\hline 4 & 43.5 & 43.5 & 43.8 \\
\hline 5 & 56.5 & 55.3 & 57.4 \\
\hline 6 & 20.9 & 21.2 & 20.8 \\
\hline 7 & 39.6 & 39.3 & 41.3 \\
\hline 8 & 48.3 & 41.8 & 48.6 \\
\hline 9 & 48.0 & 55.2 & 54.0 \\
\hline 10 & 39.8 & 40.6 & 37.8 \\
\hline 11 & 20.6 & 20.2 & 21.2 \\
\hline 12 & 30.4 & 37.2 & 38.7 \\
\hline 13 & 91.4 & 86.8 & 94.4 \\
\hline 14 & 48.1 & 43.4 & 54.7 \\
\hline 15 & 136.1 & 56.9 & 48.1 \\
\hline 16 & 142.6 & 76.8 & 224.0 \\
\hline 17 & 11.4 & 21.8 & 12.9 \\
\hline 18 & 180.4 & 180.3 & 176.9 \\
\hline 19 & 29.0 & 28.3 & 27.8 \\
\hline 20 & 15.3 & 15.1 & 19.0 \\
\hline $1^{\prime}$ & 96.6 & 95.8 & 95.3 \\
\hline $2^{\prime}$ & 80.1 & 79.8 & 73.8 \\
\hline $3^{\prime}$ & 87.5 & 86.8 & 77.4 \\
\hline $4^{\prime}$ & 70.2 & 69.8 & 69.9 \\
\hline $5^{\prime}$ & 77.3 & 77.2 & 77.5 \\
\hline $6^{\prime}$ & 61.4 & 61.5 & 61.2 \\
\hline $1^{\prime \prime}$ & 103.1 & 103.0 & \\
\hline $2^{\prime \prime}$ & 74.2 & 74.0 & \\
\hline $3^{\prime \prime}$ & 77.3 & 77.4 & \\
\hline $4^{\prime \prime}$ & 70.3 & 70.2 & \\
\hline $5^{\prime \prime}$ & 77.1 & 77.2 & \\
\hline $6^{\prime \prime}$ & 61.4 & 61.3 & \\
\hline $1^{\prime \prime \prime}$ & 102.5 & 102.6 & \\
\hline $2^{\prime \prime \prime}$ & 73.8 & 74.6 & \\
\hline $3^{\prime \prime \prime}$ & 77.1 & 77.0 & \\
\hline $4^{\prime \prime \prime}$ & 70.3 & 70.4 & \\
\hline $5^{\prime \prime \prime}$ & 77.4 & 77.2 & \\
\hline $6^{\prime \prime \prime}$ & 61.5 & 61.3 & \\
\hline
\end{tabular}

${ }^{\mathbf{a}}$ assignments made on the basis of HSQC and HMBC correlations; ${ }^{\mathbf{b}}$ Chemical shift values are in $\delta$ (ppm).

The molecular formula of compound 2 was determined to be $\mathrm{C}_{38} \mathrm{H}_{62} \mathrm{O}_{19}$ from the $[\mathrm{M}+\mathrm{H}]^{+}$ion at $m / z$ 823, together with an $[\mathrm{M}+\mathrm{Na}]^{+}$adduct at $m / z 845$ in the positive ESI mass spectrum, which was confirmed by the HRMS data. The ${ }^{1} \mathrm{H}-\mathrm{NMR}$ spectrum of 2 (Table 1) showed the presence of three 
methyl singlets, nine methylene and two methine protons. In the absence of any unsaturated protons together with the appearance of a methyl group at $\delta 1.27$ indicated that the structure of 2 should be similar to ent-13,16-dihydroxykauran-19-oic acid [13-14] which was supported by the $\delta_{\mathrm{C}} 76.8$ corresponding to the tertiary hydroxyl at $\mathrm{C}$-16. The presence of ent-13,16-dihydroxykaurane skeleton in 2 was supported by the key HMBC correlations: H-12/C-11, C-13, C-14, C-16; H-14/C-8, C-12, C-13, C-15, C-16; H-17/C-13, C-15, C-16 (Figure 3). The ESI MS/MS spectrum of 2 showed the fragment ions at $m / z 661,499$, and 337 corresponding to the successive loss of three hexose moieties from its $[\mathrm{M}+\mathrm{H}]^{+}$ion and this was supported by the three anomeric protons observed at $\delta 4.66,4.74$ and 4.89 in its ${ }^{1} \mathrm{H}$-NMR spectral data. Acid hydrolysis of $\mathbf{2}$ performed as in $\mathbf{1}$ afforded D-glucose confirming the three sugar molecules present in 2 as glucosyl units. The ${ }^{1} \mathrm{H}$ - and ${ }^{13} \mathrm{C}-\mathrm{NMR}$ values for all the protons and carbons were assigned on the basis of COSY, HMQC and HMBC correlations (Tables 1 and 2).

Figure 3. Key COSY and HMBC correlation of 2.

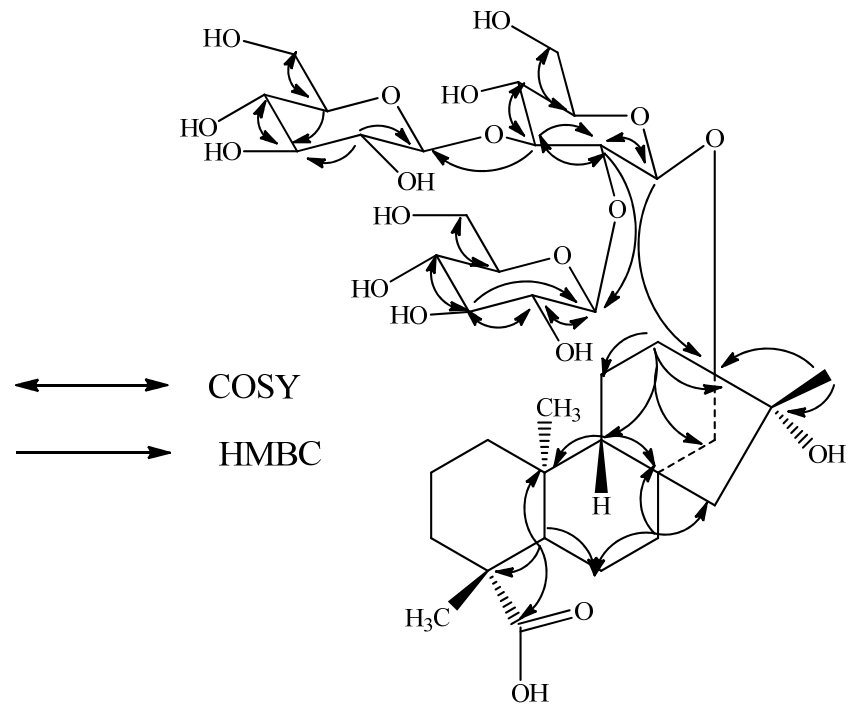

Enzymatic hydrolysis of 2 furnished a compound which was found identical to ent-13, 163-dihydroxykauran-19-oic acid on the basis of NMR spectral data comparisons [13-14]. A close comparison of the ${ }^{1} \mathrm{H}$ - and ${ }^{13} \mathrm{C}-\mathrm{NMR}$ values of 2 with those of $\mathbf{1}$ suggested the presence of three glucose units attached as a 2,3-branched $\beta$-D-glucotriosyl substituent at C-13 hydroxyl of ent-13, 163-dihydroxykauran-19-oic acid. The large coupling constants observed for the three anomeric protons of the glucose moieties at $\delta 4.66(\mathrm{~d}, J=8.2 \mathrm{~Hz}), 4.74(\mathrm{~d}, J=7.8 \mathrm{~Hz})$, and $4.89(\mathrm{~d}, J=7.8 \mathrm{~Hz})$, suggested the $\beta$-orientation as in $\mathbf{1}$. Considering the stereochemistry for the 16-hydroxyl group in 2 as $\beta$ on the basis of the acid obtained by enzymatic hydrolysis, the structure was thus deduced to be 13-[(2-O- $\beta$-D-glucopyranosyl-3-O- $\beta$-D-glucopyranosyl- $\beta$-D-glucopyranosyl)oxy]-16 $\beta$-hydroxy ent-kauran19-oic acid.

The molecular formula of compound 3 was deduced as $\mathrm{C}_{26} \mathrm{H}_{40} \mathrm{O}_{8}$ from the $[\mathrm{M}+\mathrm{H}]^{+}$ion observed at $m / z$ 481, together with an $[\mathrm{M}+\mathrm{Na}]^{+}$adduct at $m / z 503$ in the positive ESI mass spectrum and this was supported by the HRMS data. The ${ }^{1} \mathrm{H}-\mathrm{NMR}$ spectrum of $\mathbf{3}$ (Table 1) also showed the presence of three methyl singlets at $\delta 0.81,0.94$ and 1.23; nine methylene and two methine protons, similar to 2 . 
Enzymatic hydrolysis of 3 furnished a compound which was found identical to isosteviol on the basis of its NMR spectral data, identical to the reported values in the literature [14]. The presence of isosteviol skeleton was supported by the key HMBC correlations: H-12/C-9, C-11, C-13, C-14, C-16, C-17; H-14/C-8, C-12, C-13, C-15, C-16, C-17; H-15/C-8, C-14, C-16; H-17/C-13, C-14, C-16. The ${ }^{1} \mathrm{H}$ NMR spectrum also showed an anomeric proton as doublet at $\delta 5.39(\mathrm{~J}=8.2 \mathrm{~Hz})$, suggesting the presence of one sugar residue in its structure. Acid hydrolysis of 3 afforded D-glucose, confirming the sugar unit present in $\mathbf{3}$ as glucose as in $\mathbf{1}$ and $\mathbf{2}$. The placement of the glucose moiety in $\mathbf{3}$ was assigned to be at $\mathrm{C}-19$ based on the key COSY and HMBC correlations shown in Figure 4 . The ${ }^{1} \mathrm{H}$ and ${ }^{13} \mathrm{C}$ NMR values for all the protons and carbons were assigned on the basis of COSY, HMQC and HMBC correlations (Tables 1 and 2). Based on the results from chemical and spectral studies, 3 was assigned as 13-methyl-16-oxo-17-nor-ent-kauran-19-oic acid- $\beta$-D-glucopyranosyl ester.

Figure 4. Key COSY and HMBC correlations of 3.

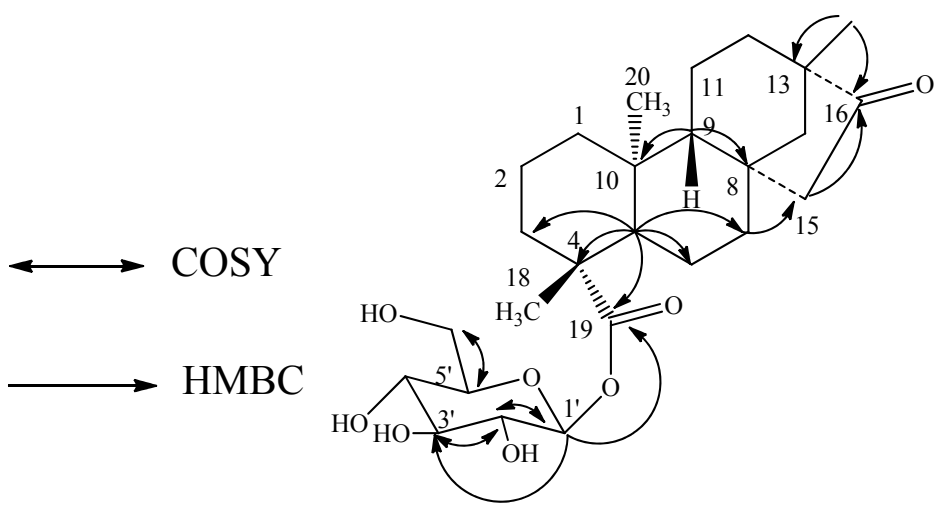

This is the first report of the occurrence of the diterpene glycosides 1-3 from $S$. rebaudiana in nature, which were reported earlier as rebaudioside A derivative/degradation products [16-17]. Also, this is the first report of their complete ${ }^{1} \mathrm{H}$ - and ${ }^{13} \mathrm{C}$-NMR spectral assignments that were made on the basis of spectral (COSY, HSQC, HMBC, and MS/MS) and chemical studies.

\section{Experimental}

\subsection{General}

Melting points were measured using a SRS Optimelt MPA 100 instrument and are uncorrected. Optical rotations were recorded using a Rudolph Autopol $\mathrm{V}$ at $25{ }^{\circ} \mathrm{C}$ and NMR spectra were acquired on Bruker Avance DRX $500 \mathrm{MHz}$ and Varian Unity Plus $600 \mathrm{MHz}$ instruments using standard pulse sequences. The spectra were referenced to the residual solvent signal $\left(\delta_{\mathrm{H}} 3.30, \delta_{\mathrm{C}} 49.0\right.$ for $\left.\mathrm{CD}_{3} \mathrm{OD}\right)$, chemical shifts are given in $\delta(\mathrm{ppm})$, and coupling constants are reported in Hz. MS and MS/MS data were generated with a Waters Premier Quadrupole Time-of-Flight (Q-Tof) mass spectrometer equipped with an electrospray ionization source operated in the positive-ion mode and Thermo Fisher Discovery OrbiTrap in the positive mode electrospray. Samples were diluted with water: acetonitrile (1:1) containing $0.1 \%$ formic acid and introduced via infusion using the onboard syringe pump. Preparative HPLC was performed on an Agilent 1100 system using a Phenomenex Prodigy ODS (3) column $(250 \times 21.2 \mathrm{~mm}, 5 \mu \mathrm{m})$. 


\subsection{Plant Material}

A commercial Stevia extract with Lot No.: 20071003 was obtained from ShenZhen NII Natural Food Ingredient Co. Ltd, China. A voucher specimen is deposited at The Coca-Cola Company, No. VSPC-3166-153.

\subsection{Isolation}

Preliminary separation of the crude extract from the leaves of S. rebaudiana SRA 40, Lot No. 20071003 consisting of a mixture of various diterpenoid glycosides including 40-60\% rebaudioside A was carried out via preparative HPLC on an Agilent 1100 system. The HPLC method A involved using Phenomenex Prodigy Column $\mathrm{C}_{18}(250 \times 10 \mathrm{~mm}, 10 \mu \mathrm{m})$; UV Detection: $220 \mathrm{~nm}$; Mobile Phase A: $\mathrm{H}_{2} \mathrm{O}(0.1 \%$ TFA); Mobile Phase B: Acetonitrile; Flow Rate: $5.0 \mathrm{~mL} / \mathrm{min}$; Injection volume: $400 \mu \mathrm{L}$. The gradient increased from 95: 5 (A: B) to 0: 100 (A: B) over $30 \mathrm{~min}$, and remained at 0: 100 (A: B) for $5 \mathrm{~min}$. Removal of the dominant rebaudioside $\mathrm{A}\left(t_{R} 17.13 \mathrm{~min}\right)$ using the above HPLC method and subsequent collection of the peak eluting at $t_{R} 14.60 \mathrm{~min}$ over multiple runs furnished 1 (4.6 mg). The peak eluting at $t_{R} 12.86$ min contained a mixture of 2 along with several other compounds. Since 2 was only partially resolved under the first HPLC method, a second round of purification was applied to isolate the pure compound. This was carried out using HPLC method B which was a modification to HPLC method A using the gradient of 80: 20 (A: B) to 70: 30 (A: B) applied for 40 min. The peak eluted at $t_{R} 32.4 \mathrm{~min}$ was confirmed to correspond to $2(3 \mathrm{mg})$. Similar to 1 , removal of rebaudioside A and combining the peak eluted at $t_{R} 18.2$ min using HPLC method A over multiple runs and concentration under vacuum furnished $3(4.2 \mathrm{mg})$. All the known compounds were identified using HPLC-MS in comparison with authentic standards as described previously [6] and the spectral data that were reported in the literature [7-13].

13-[(2-O- $\beta$-D-glucopyranosyl-3-O- $\beta$-D-glucopyranosyl- $\beta$-D-glucopyranosyl)oxy] ent-kaur-15-en-19-oic acid (1). White powder, mp $254.5-254.7{ }^{\circ} \mathrm{C},[\alpha]_{\mathrm{D}}{ }^{25}-49.56$ (c 1.0, MeOH); ${ }^{1} \mathrm{H}-\mathrm{NMR}(500 \mathrm{MHz}$, $\left.\mathrm{CD}_{3} \mathrm{OD}, \delta \mathrm{ppm}\right)$ and ${ }^{13} \mathrm{C}-\mathrm{NMR}\left(125 \mathrm{MHz}, \mathrm{CD}_{3} \mathrm{OD}, \delta \mathrm{ppm}\right)$ spectroscopic data see Tables 1 and 2; HRMS $(\mathrm{M}+\mathrm{Na})^{+} m / z 827.3661$ (calcd. for $\mathrm{C}_{38} \mathrm{H}_{60} \mathrm{O}_{18} \mathrm{Na}$ : 827.3677)

Enzymatic hydrolysis of $\mathbf{1}$. A solution of $\mathbf{1}(250 \mu \mathrm{g})$ was dissolved in $0.1 \mathrm{M}$ sodium acetate buffer, $\mathrm{pH}$ $4.5(2.5 \mathrm{~mL})$ and crude pectinase from Aspergillus niger (50 $\mu \mathrm{L}$, Sigma-Aldrich, P2736) was added. The mixture was stirred at $50{ }^{\circ} \mathrm{C}$ for $48 \mathrm{hr}$. The product precipitated out during the reaction and was filtered and then crystallized from methanol $(\mathrm{MeOH})$. The resulting product was identical to ent-13-hydroxykaur-15-en-19-oic acid by comparison of their ${ }^{1} \mathrm{H}-\mathrm{NMR}$ spectral data [13-14].

Acid Hydrolysis of 1. Compound $1(500 \mu \mathrm{g})$ was hydrolyzed with $0.5 \mathrm{M} \mathrm{HCl}(0.5 \mathrm{~mL})$ for $1.5 \mathrm{~h}$. After cooling, the mixture was passed through an Amberlite IRA400 column and the eluate was lyophilized. The residue was dissolved in pyridine $(0.25 \mathrm{~mL})$ and heated with L-cysteine methyl ester $\mathrm{HCl}(2.5 \mathrm{mg})$ at $60{ }^{\circ} \mathrm{C}$ for $1.5 \mathrm{~h}$, and then $O$-tolyl isothiocyanate $(12.5 \mu \mathrm{L})$ was added to the mixture and heated at 60 ${ }^{\circ} \mathrm{C}$ for an additional $1.5 \mathrm{~h}$. The reaction mixture was analyzed by HPLC: column Phenomenex Luna 
C18, $150 \times 4.6 \mathrm{~mm}(5 \mathrm{u}) ; 25 \%$ acetonitrile- $0.2 \%$ TFA water, $1 \mathrm{~mL} / \mathrm{min}$; UV detection at $250 \mathrm{~nm}$. The sugar was identified as D-glucose $(t \mathrm{R}, 12.26 \mathrm{~min})$ [authentic samples, D-glucose $(t \mathrm{R}, 12.35)$ and L-glucose $(t \mathrm{R}, 11.12 \mathrm{~min})]$ [15].

13-[(2-O- $\beta$-D-glucopyranosyl-3-O- $\beta$-D-glucopyranosyl- $\beta$-D-glucopyranosyl)oxy]-16 $\beta$-hydroxy-entkauran-19-oic acid (2). White powder, mp 220.4-221.2 ${ }^{\circ} \mathrm{C},[\alpha]_{\mathrm{D}}{ }^{25}-32.60$ (c 1.0, MeOH); ${ }^{1} \mathrm{H}-\mathrm{NMR}$ $\left(500 \mathrm{MHz}, \mathrm{CD}_{3} \mathrm{OD}, \delta \mathrm{ppm}\right)$ and ${ }^{13} \mathrm{C}-\mathrm{NMR}\left(125 \mathrm{MHz}, \mathrm{CD}_{3} \mathrm{OD}, \delta \mathrm{ppm}\right)$ spectroscopic data see Tables 1 and 2; HRMS $(\mathrm{M}+\mathrm{Na})^{+} m / z 845.3765$ (calcd. for $\mathrm{C}_{38} \mathrm{H}_{62} \mathrm{O}_{19} \mathrm{Na}$ : 845.3783)

Enzymatic hydrolysis of 2. Enzymatic hydrolysis of $2(500 \mu \mathrm{g})$ as described above furnished ent-13, $16 \beta$-dihydroxykauran-19-oic acid which was confirmed on the basis of ${ }^{1} \mathrm{H}$ NMR spectral data $[13,14]$.

Acid Hydrolysis of $\mathbf{2}$. Hydrolysis of $\mathbf{2}(500 \mu \mathrm{g})$ as described above furnished D-glucose [15].

13-methyl-16-oxo-17-nor-ent-kauran-19-oic acid- $\beta$-D-glucopyranosyl ester (3). White powder, mp $172.5{ }^{\circ} \mathrm{C},[\alpha]_{\mathrm{D}}{ }^{25}-55.83$ (c 1.0, EtOH); ${ }^{1} \mathrm{H}-\mathrm{NMR}\left(500 \mathrm{MHz}, \mathrm{CD}_{3} \mathrm{OD}, \delta \mathrm{ppm}\right)$ and ${ }^{13} \mathrm{C}-\mathrm{NMR}(125 \mathrm{MHz}$, $\left.\mathrm{CD}_{3} \mathrm{OD}, \delta \mathrm{ppm}\right)$ spectroscopic data see Tables 1 and 2; HRMS $(\mathrm{M}+\mathrm{Na})^{+} \mathrm{m} / z 503.2608$ (calcd. for $\left.\mathrm{C}_{26} \mathrm{H}_{40} \mathrm{O}_{8} \mathrm{Na}: 503.2621\right)$

Enzymatic hydrolysis of $\mathbf{3}$. Enzymatic hydrolysis of $\mathbf{3}(500 \mu \mathrm{g})$ as described above furnished isosteviol which was confirmed on the basis of ${ }^{1} \mathrm{H}-\mathrm{NMR}$ spectral data [14].

Acid Hydrolysis of 3. Hydrolysis of $2(500 \mu \mathrm{g})$ as described above furnished D-glucose [15].

\section{Conclusions}

Three diterpenoid glycosides 1-3 were isolated from a commercial extract of the leaves of $S$. rebaudiana obtained from ShenZhen NII Natural Food Ingredient Co. Ltd, China, along with the known steviol glycosides stevioside, rebaudiosides A-F, rubusoside and dulcoside $\mathrm{A}$. The new compounds were identified as 13-[(2-O- $\beta$-D-glucopyranosyl-3-O- $\beta$-D-glucopyranosyl- $\beta$-D-glucopyranosyl)oxy] ent-kaur-15-en-19-oic acid, 13-[(2-O- $\beta$-D-glucopyranosyl-3-O- $\beta$-D-glucopyranosyl- $\beta$ D-glucopyranosyl)oxy]-16 $\beta$-hydroxy-ent-kauran-19-oic acid, 13-methyl-16-oxo-17-nor-ent-kauran-19oic acid- $\beta$-D-glucopyranosyl ester on the basis of spectroscopic and chemical studies. This is the first report of the isolation of these three diterpene glycosides from $S$. rebaudiana in nature. The discovery of these compounds is an important addition in expanding our understanding of the diversity of the diterpenoid glycosides present in the $S$. rebaudiana.

\section{Acknowledgements}

We wish to thank ShenZhen NII Natural Food Ingredient Co. Ltd, China for providing the Stevia extract. 


\section{References and Notes}

1. Mosettig, E.; Nes, W.R. Stevioside. II. The structure of the aglucon. J. Org. Chem. 1955, 20, 884-899.

2. Mosettig, E.; Beglinger, U.; Dolder, F.; Lichiti, H.; Quitt, P.; Waters, J.A. The absolute configuration of steviol and isosteviol. J. Am. Chem. Soc. 1963, 85, 2305.

3. Brandle, J.E.; Starrratt, A.N.; Gijen, M. Stevia rebaudiana: Its agricultural, biological and chemical properties. Can. J. Plant Sci. 1998, 78, 527-536.

4. Chaturvedula, V.S.P.; Rhea, J.; Milanowski, D.; Mocek, U., Prakash, I. Two minor diterpene glycosides from the leaves of Stevia rebaudiana. Nat. Prod. Commun. 2011, 6, 175-178.

5. Chaturvedula, V.S.P.; Clos, J.F.; Rhea, J.; Milanowski, D.; Mocek, U.; DuBois, G.E.; Prakash, I. Minor diterpenoid glycosides from the leaves of Stevia rebaudiana. Phytochemistry Lett. 2011. (in press)

6. Clos, J.F.; DuBois, G.E.; Prakash, I. Photostability of rebaudioside a and stevioside in beverages. J. Agric. Food Chem. 2008, 56, 8507-8513.

7. Kohda, H.; Kasai, R.; Yamsaki, K.; Murakami, K.; Tanaka, O. New sweet diterpene glucosides from Stevia rebaudiana. Phytochemistry 1976, 15, 981-983.

8. Kobayashi, M.; Horikawa, S.; Degrandi, I.H.; Ueno, J.; Mitsuhashi, H. Dulcosides A and B, new diterpene glycosides from Stevia rebaudiana. Phytochemistry 1977, 16, 1405-1408.

9. Starratt, A.N.; Kirby, C.W.; Pocs, R.; Brandle, J.E. Rebaudioside F, a diterpene glycoside from Stevia rebaudiana. Phytochemistry 2002, 59, 367-370.

10. Sakamoto, I.; Yamasaki, K.; Tanaka, O. Application of ${ }^{13} \mathrm{C}$ NMR spectroscopy to the chemistry of natural glycosides: rebaudioside C, a new sweet diterpene glycoside of Stevia rebaudiana. Chem. Pharm. Bull. 1977, 25, 844-846.

11. Sakamoto, I.; Yamasaki, K.; Tanaka, O. Application of ${ }^{13} \mathrm{C}$ NMR spectroscopy to chemistry of plant glycosides: rebaudiosides D and E, new sweet diterpene glucosides of Stevia rebaudiana Bertoni. Chem. Pharm. Bull. 1977, 25, 3437-3439.

12. Ohta, M.; Sasa, S.; Inoue, A.; Tamai, T.; Fujita, I.; Morita, K.; Matsuura, F. Characterization of novel steviol glycosides from leaves of Stevia rebaudiana Morita, J. Appl. Glycosci. 2010, 57, 199-209.

13. Ohtani, K.; Aikawa, Y.; Kasai, R.; Chou, W.; Yamasaki, K.; Tanaka, O. Minor diterpene glycosides from sweet leaves of Rubus suavissimus. Phytochemistry 1992, 31, 1553-1559.

14. Avent, A.G.; Hanson, J.R.; de Oliviera, B.H. Hydrolysis of the diterpenoid glycoside, Stevioside. Phytochemistry 1990, 29, 2712-2715.

15. Tanaka, T.; Nakashima, T.; Ueda, T.; Tomii, K.; Kouno, I. Facile discrimination of aldose enantiomers by reversed-phase HPLC. Chem. Pharm. Bull. 2007, 55, 899-901.

16. Prakash, I.; DuBois, G.E.; San Miguel, R.I.; Clos, J.F. Rebaudioside A derivatives and methods for Making. PCT Int. Appl. 2009, 108680 A2, 66 pp.(or pp. 66.)

17. Lee, T. Steviol glycoside isomers for use as sweeteners in food and beverage products. PCT Int. Appl. 2009, 2009038978 A2, 58 pp. (or pp. 58.) 
Sample Availability: Samples of the new diterpene glycoside 1-3, and the known steviol glycosides stevioside, rebaudiosides A-F, rubusoside and dulcoside A are available from the authors.

(C) 2011 by the authors; licensee MDPI, Basel, Switzerland. This article is an open access article distributed under the terms and conditions of the Creative Commons Attribution license (http://creativecommons.org/licenses/by/3.0/). 